\title{
Tn5041: a chimeric mercury resistance transposon closely related to the toluene degradative transposon Tn4651
}

\author{
G. Ya. Kholodii, † O. V. Yurieva, Zh. M. Gorlenko, S. Z. Mindlin, I. A. Bass, \\ O. L. Lomovskaya, $\neq$ A. V. Kopteva and V. G. Nikiforov
}

Author for correspondence: V. G. Nikiforov. Tel: +7 0951960015 . Fax: +7 0951960221. e-mail: uimg@img.rc.ac.ru

Institute of Molecular Genetics, Russian Academy of Sciences, Moscow 123182, Russia

\begin{abstract}
This paper reports the discovery and characterization of Tn5041, a novel-type transposon vehicle for dissemination of mercury resistance in natural bacterial populations. Tn5041 (14876 bp), identified in a Pseudomonas strain from a mercury mine, is a In 3 family mercury resistance transposon far outside the Tn21 subgroup. As in other Tn3 family transposons, Tn5041 duplicates 5 bp of the target sequence following insertion. Tn5041 apparently acquired its mer operon as a single-ended relic of a transposon belonging to the classical mercury resistance transposons of the $\mathrm{Tn} 21$ subgroup. The putative transposase and the $47 \mathrm{bp}$ terminal inverted repeats of Tn5041 are closely related to those of the toluene degradative transposon Tn4651 and fall into a distinct subgroup on the fringe of the Tn 3 family. The amino acid sequence of the putative resolvase of $\mathrm{Tn} 5041$ resembles site-specific recombinases of the integrase family. Besides the mer operon and putative transposition genes, Tn5041 contains a $4 \mathrm{~kb}$ region that accommodates a number of apparently defective genes and mobile elements.
\end{abstract}

Keywords: $\operatorname{Tn} 5041$, mer operon, $\operatorname{Tn} 3$ family, integrase, transposase

\section{INTRODUCTION}

Mercury resistance in bacteria is a widespread phenotype. As a rule, it is determined by several genes organized into a mercury resistance (mer) operon. These are often located on plasmids and transposons (Silver \& Walderhaug, 1992; Misra, 1992). The first well-characterized mercury resistance transposons, Tn501 and Tn21, were from clinical isolates. Tn501 was isolated from a Pseudomonas aeruginosa strain from Australia (Stanisich et al., 1977). Tn21 was found in the plasmid NR1 in Shigella flexneri isolated in Japan (Womble \& Rownd, 1988; Grinsted et al., 1990). Besides the mer operon and transposition genes Tn21 contains an integron carrying the antibiotic resistance genes sul and

\footnotetext{
†Present address: The Rockefeller University, New York, NY 10021, USA. ¥Present address: Microcide Pharmaceuticals, 850 Maude Ave, Mountain View, CA 94043, USA.

Abbreviations: IR, inverted repeat; IS, insertion sequence; PMA, phenylmercuric acetate.

The EMBL accession number for the nucleotide sequence of Tn5041 reported in this paper is $X 98999$.
}

str (Brown et al., 1996). A plethora of transposons closely related to $\operatorname{Tn} 21$ and carrying different sets of antibiotic resistance genes has been detected in clinical isolates (for review see Grinsted et al., 1990). Tn3926, which is homologous to both Tn501 and Tn21, was identified in Yersinia enterocolitica isolated from raw milk in France (Lett et al., 1985). Tn21, Tn3926 and Tn501 define a compact group within the $\operatorname{Tn} 3$ family of transposons. They are bound by $38 \mathrm{bp}$ inverted repeats (IRs) and contain two genes, $\operatorname{tn} p R$ and $\operatorname{tn} p A$, which are involved in transposition (Grinsted et al., 1990; Osbourn et al., 1995).

Several mercury resistance transposons from environmental bacteria have been described less thoroughly. Tn1861 from Pseudomonas putida has a restriction pattern similar to Tn501 (Friello \& Chakrabarty, 1980). The apparently identical Tn3402 and Tn3403 (Radford et al., 1981) have a characteristic pattern of EcoRI and HindIII sites in the transposition genes, similar to that of Tn21 (A. J. Radford, cited by Stanisich et al., 1989). Thus, until recently, all mercury resistance transposons described from Gram-negative bacteria were apparently related to Tn21 and Tn501 with the possible exception 
of the poorly characterized Tn502 (Stanisich et al., 1989; Brown et al., 1996).

The first 'novel-type' mer transposon to be characterized was Tn5053 (Kholodii et al., 1993). Tn5053 apparently acquired its mer operon, merRTPFAD, as a single-ended relic of another transposon which is closely related to the classical mercury resistance transposons $\operatorname{Tn} 21$ and $\operatorname{Tn} 501$. The transposition module of Tn5053 is quite different from transposition modules of classical transposons of the $\mathrm{Tn} 21$ subgroup, but is closely related to a family of transposons carrying integrons (Kholodii et al., 1995; Brown et al., 1996). Tn5053 is bounded by $25 \mathrm{bp}$ terminal inverted repeats and contains four genes involved in transposition, tniA, tniB, tniQ and tniR. Transposition of Tn5053 occurs via cointegrate formation mediated by the products of the tni $A B Q$ genes, followed by site-specific cointegrate resolution. This is catalysed by the product of the tniR gene at the res region, which is located upstream of $t n i R$. Sequence analysis suggests that $\operatorname{Tn} 5053$ fell into a recently recognized superfamily of transposons including retroviruses, Tn7, and insertion sequences of the IS3 family (Kholodii et al., 1995).

In this communication we describe the isolation and complete nucleotide sequence of another 'novel-type' mercury resistance transposon, Tn5041, which was identified in a Pseudomonas strain from a mercury mine. As is the case with $\operatorname{Tn} 5053, \operatorname{Tn} 5041$ apparently acquired its mer operon from a transposon belonging to the $\operatorname{Tn} 21$ subgroup. The transposition module of Tn 5041 belongs to the Tn 3 family but is far outside the Tn21 subgroup.

\section{METHODS}

Bacterial strains and plasmids. The following bacterial strains and plasmids were used: Pseudomonas spp. KHP41 and KHP22 (Bogdanova et al., 1988); Escherichia coli K-12 strains AB1456 (a recipient in transposition experiments); JM83 (a host strain for pUC19-based recombinant plasmids); HB101 (a host for mer operon containing plasmids in mercury resistance testing) ; RP1 (Pansegrau et al., 1994); RP1 :: Tn5041 (this paper); R831b (merB ${ }^{+}$) (Schottel et al., 1974); $\mathrm{pVS982=}$ pBR322::Tn501 (merB) (Grinsted et al., 1982). pWWO containing Tn4651 (Tsuda et al., 1989) was obtained from Dr K. N. Timmis.

Mercury resistance testing. Susceptibility to $\mathrm{HgCl}_{2}$ and phenylmercuric acetate (PMA) was determined by the disk diffusion method. LB agar $(1.8 \%)$ was overlaid with $5 \mathrm{ml}$ $0.5 \%$ LB agar containing $0.1 \mathrm{ml}$ late-exponential-phase bacterial culture of $\mathrm{HB} 101$ with or without a plasmid. Filter paper disks (6 mm diameter) loaded with $5-40 \mu \mathrm{g} \mathrm{HgCl}_{2}$ or $2-20 \mu \mathrm{g}$ PMA were placed on the plates. The growth inhibition zones were measured after incubation at $30^{\circ} \mathrm{C}$ for $20 \mathrm{~h}$. All the assays were repeated at least three times. With $10 \mu \mathrm{g}$ PMA, inhibition zones were about $5 \mathrm{~mm}$ for PMA-sensitive strains (HB101 without plasmids or with pVS982, or RP1, or RP1:: Tn5041) and about $1.5 \mathrm{~mm}$ for the PMA-resistant strain ( $\mathrm{HB101}$ bearing $\mathrm{R} 831 \mathrm{~b}$ ). Inhibition zones for $\mathrm{HgCl}_{2}$ (at $20 \mu \mathrm{g}$ ) were about $6 \mathrm{~mm}$ for HB101 without plasmids or with RP1 and about $2 \mathrm{~mm}$ for HB101 with any other plasmid mentioned above.
Detection of mercury resistance transposons. This was done by introducing the broad-host-range plasmid RP1 into spontaneous rifampicin-resistant mutants of mercury-resistant Pseudomonas/Xanthomonas strains by conjugation from a rifampicin-sensitive $E$. coli donor strain. The matings were performed on solid LB medium. LB agar supplemented with kanamycin $\left(50 \mu \mathrm{g} \mathrm{ml}^{-1}\right)$ and rifampicin $\left(30 \mu \mathrm{g} \mathrm{ml}^{-1}\right)$ was used for selecting of RP1-containing transconjugants. After 2-3 serial transfers on selective medium containing kanamycin $\left(50 \mu \mathrm{g} \mathrm{ml}^{-1}\right)$ and $\mathrm{HgCl}_{2}\left(4 \mu \mathrm{g} \mathrm{ml}^{-1}\right)$ the transconjugants were mated with a streptomycin-resistant recipient $E$. coli strain AB1456 (str-r) and RP1-Hg-r recombinant plasmid-containing clones were isolated on $\mathrm{LB}$ agar supplemented with $\mathrm{HgCl}_{2}$ $\left(4-5 \mu \mathrm{g} \mathrm{ml}^{-1}\right)$ and streptomycin $\left(100 \mu \mathrm{g} \mathrm{ml}^{-1}\right)$.

Cloning and other DNA manipulations. These were carried out according to Sambrook et al. (1989). Tn5041 transposed to RP1 was subcloned in pUC19 and sequenced using the Maxam-Gilbert method (Sambrook et al., 1989). Tn5041related elements were detected by colony hybridization with ${ }^{32} \mathrm{P}$-labelled fragments of transposition genes of $\mathrm{Tn} 5041$. Plasmidal localization of these elements was checked by Southern hybridization of Tn5041-specific probes with DNA preparations isolated from tested mercury-resistant strains by an alkaline extraction procedure (Birnboim \& Doly, 1979). Database search was performed with the BLAST program (Altschul et al., 1990). Sequence alignment of Tn3 family transposases and tree constructions were performed using the program vosToRg (Zharkikh et al., 1991). In the case of Tn4556 transposase, the published nucleotide sequence (Siemieniak et al., 1990) apparently contained a small number of frame-shifting sequence errors. Our corrections resulted in identification of a well-conserved $\mathrm{NH}_{2}$-terminal segment $(130$ residues) of the Tn4556 transposase which was missing in the published amino acid sequence and considerable improvement of the alignment of the following 70 amino acid residues.

\section{RESULTS AND DISCUSSION}

\section{Detection of Tn5041 and related elements}

For detection of mercury resistance transposons, we used a collection of mercury-resistant Pseudomonas/ Xanthomonas strains isolated from a mercury mine in Kirgizia, Central Asia (Khesin \& Karasyova, 1984; Bogdanova et al., 1988). In most of these strains, mer operons were located on $100 \mathrm{MDa}$ narrow-host-range plasmids that were readily transferred by conjugation to their mercury-sensitive plasmid-cured derivatives but not to any Pseudomonas or E. coli strains tested (Khesin \& Karasyova, 1984; Zh. Gorlenko \& S. Z. Mindlin, unpublished). We surveyed this collection by introducing the broad-host-range plasmid RP1 and mating out to E. coli as described in Methods. As in the case of Gram-negative mercury-resistant strains described by Kelly \& Reanney (1984), some strains from our collection (12 out of 23 tested) were refractory to introduction of RP1. For some strains, this may be due to incompatibility or surface exclusion by resident plasmids because plasmids of the same incompatibility group as RP1 can be found in some environmental bacteria (Amuthan \& Mahadevan, 1994) and narrow-host-range plasmids showing incompatibility with RP1 are known (Smith \& Thomas, 1987). For one strain (KHP22) tested, we demonstrated that the resistance to RP1 was not due 

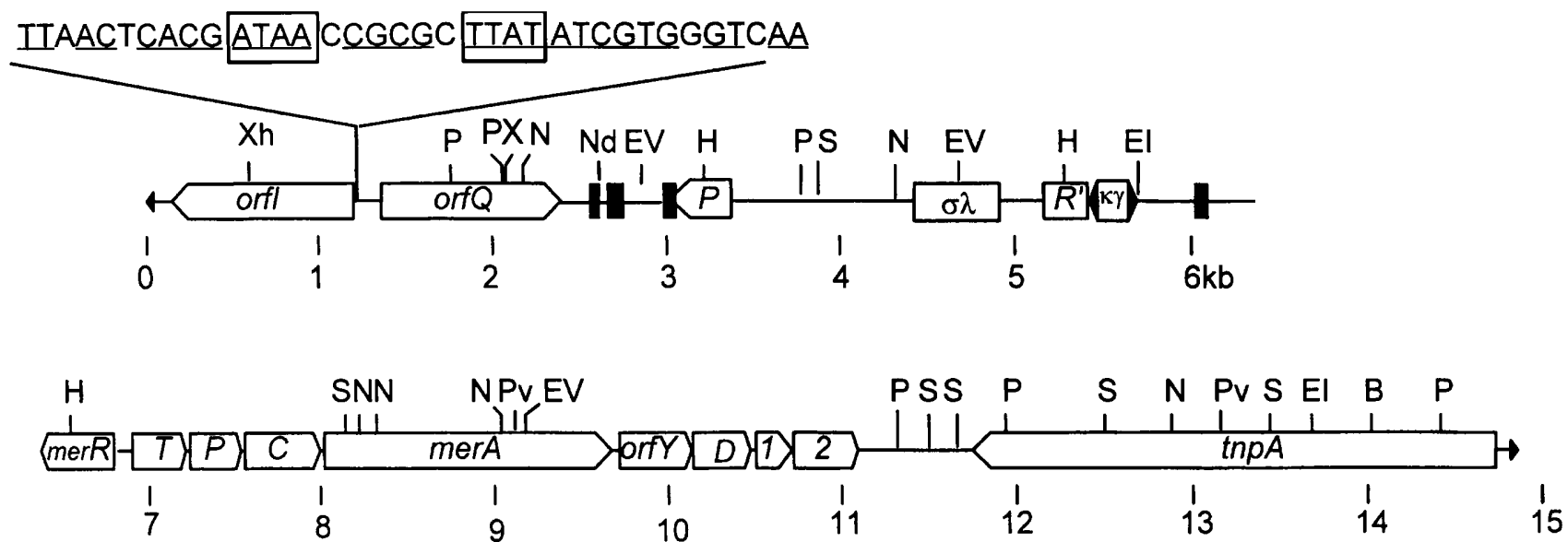

Fig. 1. Genetic organization of Tn5041. The terminal $47 \mathrm{bp} \mathrm{IRs}$ are shown by solid arrowheads. The location and polarity of genes and ORFs is shown by open arrows. $T, P, C$ and $D$ indicate the corresponding mer genes, and 1 and 2 indicate homologues of urf-1 and urf-2, respectively. $P$ denotes orfP encoding a porin-like protein. $R^{\prime}$ is a truncated copy of merR located in the same orientation as the functional copy of merR. $\sigma \lambda$ and $\kappa \gamma$ are relics of mobile elements. Solid rectangles represent segments encoding amino acid sequences showing similarity to segments of a rat membrane protein located in the same order (Hallberg et al., 1993). The sequence of a putative res site is shown above the 141 bp spacer located between orfl and orfQ (bases forming a palindrome are underlined, those shared with the dif site are boxed). Restriction sites: B, Bg/ll; E, EcoRl; EV, EcoRV; H, HindlII; N, Ncol; Nd, Ndel; P, Pstl; Pv, Pvull; S, Sall; X, Xbal; Xh, Xhol.

to the resident plasmid since a mercury-sensitive derivative of KHP22 which was cured of its single $100 \mathrm{MDa}$ plasmid (Khesin \& Karasyova, 1984) was still refractory to introduction of RP1.

Four out of eleven RP1-accepting strains gave mercuryresistant transconjugants with frequencies about $10^{-5}$ per RP1-containing transconjugant. One of these strains contained a novel mercury resistance transposon, Tn5053, which was described previously by Kholodii et al. (1993, 1995). Restriction analysis of plasmid DNA of mercury-resistant transconjugants obtained from Pseudomonas sp. strain KHP41 revealed insertions of about $15 \mathrm{~kb}$ in a segment of RP1 located between ori $\mathrm{V}$ and Tn1. Sequencing of the junction between RP1 and the inserted element in three independent transconjugants revealed insertions of the same sequence after positions (numbering according to Pansegrau et al., 1994) 11019 of RP1 (the beginning of the klcB gene), 12025 and 12212 (a non-coding region at the border of oriV). Insertions of the element, $\operatorname{Tn} 5041$, resulted in duplications of $5 \mathrm{bp}$ of the target sequence (GTATT, CTTTG and GGCAC, respectively).

Most mercury resistance determinants with a few possible exceptions (Witte et al., 1986; Mahler et al., 1986; Wang et al., 1987; Shiratori et al., 1989; Kholodii et al., 1993) were found on plasmids. A $4.2 \mathrm{~kb}$ plasmid, which was too small to accommodate Tn5041, and no large plasmids were found in strain KHP41 using both an alkaline extraction procedure (Birnboim \& Doly, 1979) and agarose gel electrophoresis of crude extracts by the method described by Eckhardt (1978). Chromosomal DNA preparations from KHP41 showed hybridization with Tn5041-specific DNA probes while plasmid DNA preparations did not (data not shown).
Thus, Tn5041 was apparently localized chromosomally. As in other reported cases of apparent chromosomal location of mercury resistance determinants, the possibility was not excluded that Tn 5041 was actually located on a megaplasmid which often go undetected by common methods (Barton et al., 1995). DNA elements showing hybridization with Tn5041 transposition genes were found in $100 \mathrm{MDa}$ plasmids readily detected in three other Pseudomonas strains isolated from the same mine as KHP41 (see Methods). We failed to check transposability of these elements since their host strains were refractory to introduction of RP1. We demonstrated that about $10 \%$ of environmental Pseudomonas mercury-resistant strains collected in other parts of the world contained DNA elements showing hybridization with Tn5041 transposition genes. One of these strains contained a functional transposon similar to Tn5041 while other were either resistant to RP1 or transposition deficient. We found no elements related to Tn5041 in our collection of Acinetobacter and enterobacterial strains.

\section{Tn5041 belongs to the Tn3 family}

We determined the complete nucleotide sequence of Tn5041 on both strands as described in Methods. Results of sequence analysis are summarized in Fig. 1. Tn5041 is bound by 47 bp imperfect inverted repeats which are closely related to IRs of the toluene degradative transposon Tn4651 (Tsuda et al., 1989). The 38 outermost base pairs of these IRs show similarity to IRs of the Tn3 family transposons (Fig. 2a).

At the right arm of Tn5041, a large ORF is situated encoding a protein (995 amino acid residues) showing $96.1 \%$ identity with a transposase of a $\operatorname{Tn} 3$ family 
(a)

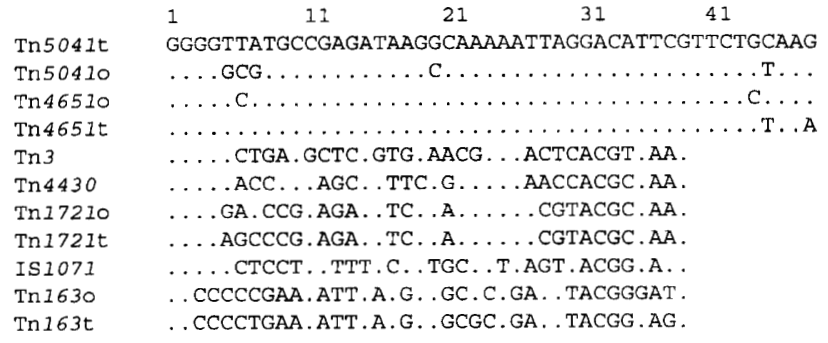

(b)

\begin{tabular}{|c|c|}
\hline$\kappa \gamma L$ & GGGGGTTGGGGAGCAATGGAACTGAAAACCAACGTAAG \\
\hline$\kappa \gamma \mathrm{R}$ & $\ldots$.. G..............GTGC . T.. \\
\hline $\operatorname{Tr} 1412$ & $\ldots$. \\
\hline$a v r B$ & Т... Т.... \\
\hline$m k f A$ & T..T............ . .GCCGT. \\
\hline 'res501' & $\ldots$. . . A. . CA . . . . . . . . GGAGC . T . . \\
\hline $\operatorname{Tn} 5396 t$ & 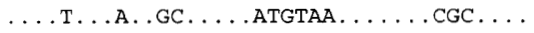 \\
\hline $\operatorname{Tn} 53960$ & $\ldots$ T. . A. .GC . . ATG.AA. . . . CGC . . \\
\hline $\operatorname{Tn} 1000 t$ & $\ldots$. . . A. .GC. . . . . . GA. . CGT. CGT . . \\
\hline $\operatorname{Tn} 10000$ & 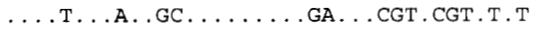 \\
\hline $\operatorname{Tn} 5401$ & $\ldots$. TA. .T. . . . . . . . . TCA.GCAAC . \\
\hline $\operatorname{Tn} 4556 \mathrm{t}$ & C.......... A. .TCC ... GA. . C.GGCGC . . \\
\hline $\operatorname{Tn} 45560$ & 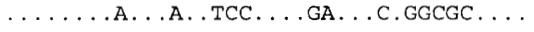 \\
\hline
\end{tabular}

Fig. 2. Comparison of terminal IRs of (a) Tn5041 and (b) of an $\kappa \gamma$ element located within Tn5041 with selected IRs of the Tn3 family transposons. Letters following names of transposons are showing locations of IRs in those cases when the IRs are not the same (' $\mathrm{t}$ ' indicates the tnpA end and ' $\mathrm{O}$ ' the other end). Dots represent bases identical with those in the upper sequence. Accession nos (or references): Tn5041, X98999; Tn4651 (Tsuda et al., 1989); avrB, M21965; Tn5396, U04360 and U04362; mkfA, X16098; 'res501' (located between resill and tnpR in Tn501), X03406; Tn1721, X61367. Other accession nos are listed in the legend to Fig. 3.

toluene degradative transposon Tn4651 (EMBL accession no. X83686; Dr R. Horak). Accordingly, we suggest that this ORF which we designated $\operatorname{tn} p A$ (Fig. 1) encodes the Tn5041 transposase.

To find the exact position of $\operatorname{Tn} 5041$ in the $\operatorname{Tn} 3$ family we aligned its putative transposase with $20 \mathrm{Tn} 3$ family transposases which we found in the databases. Analysis of the alignment demonstrated that most of the transposases clustered around three previously recognized subgroups. The first cluster united a compact Tn21 subgroup (including $\operatorname{Tn} 21, \operatorname{Tn} 3926, \operatorname{Tn} 501$ and $\operatorname{Tn} 1721$ ) (Grinsted et al., 1990) with the more distantly related Tn2501 (Turner \& Grinsted, 1987). Tn5393 (Chiou \& Jones, 1993) and Tn163 (Ulrich \& Puehler, 1994) can be also affiliated to this cluster on the basis of analysis of the more conserved $\mathrm{COOH}$-terminal part of the transposase protein (Fig. 3). The second cluster contained transposons from Gram-positive bacteria only: Tn917 (An \& Clewell, 1991), Tn5422 (Lebrun et al., 1994), Tn1546 (Arthur et al., 1993), Tn4430 (Mahillon \& Lereclus, 1988), and a putative transposon from Bacillus firmus (Ivey et al., 1992). The third cluster included Tn3 and Tn1000 (Grinsted et al., 1990), Tn5396 (Elhai et al., 1994), Tn1412 (accession no. L36547), Tn5401 (Baum,

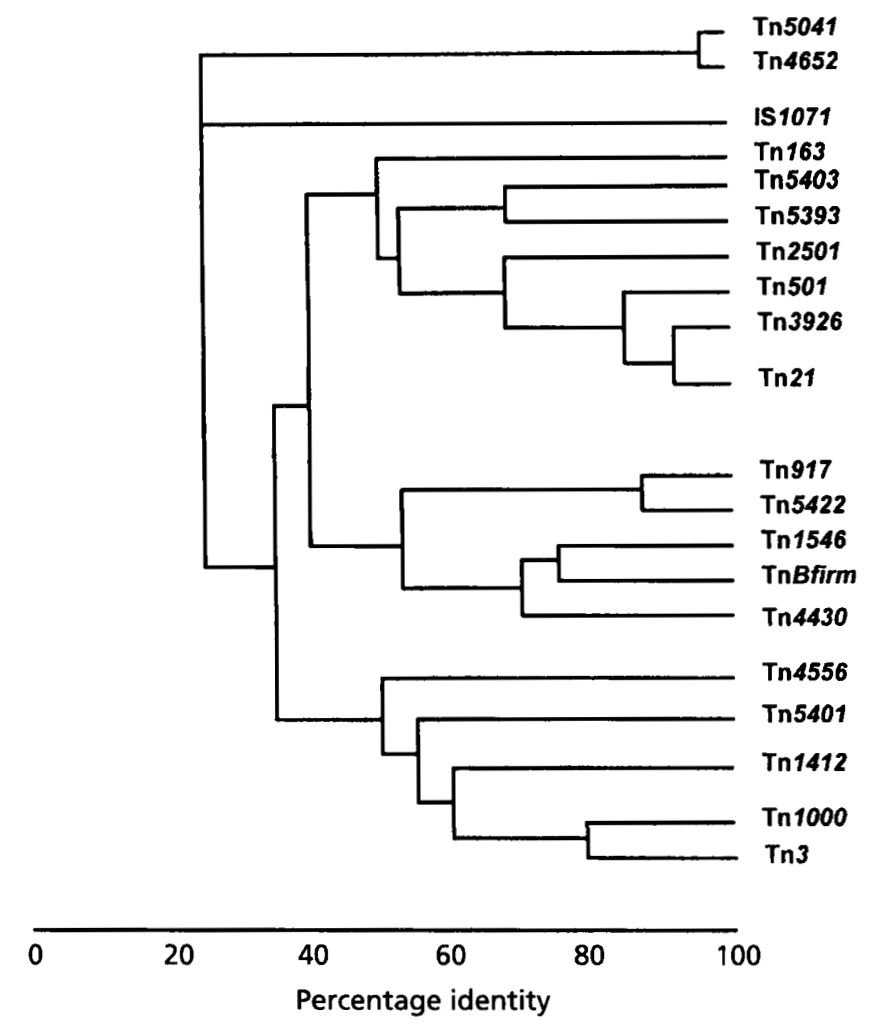

Fig. 3. Evolutionary tree of $\operatorname{Tn} 3$ family transposons based on comparison of the $\mathrm{COOH}$-terminal-third of their transposases. Accession nos: Tn21, X04891; Tn3926, X14236; Tn501, X03406; Tn2501, Y00502; Tn5393, M96392; Tn5403, X75779; Tn163, L14931; Tn917, M11180; Tn5422, L28104; Tn1546, M97297; Tn4430, X07651; Tn3, V00613; Tn1000, X60200; Tn1412, L36547; Tn5401, U03554; Tn4556, M29297; IS1071, M65135; Tn4651, X83686; Tn5041, X98999.

1994) and Tn4556 (Siemieniak et al., 1990). Only three transposases were definitely outside the aggregate of the above clusters even when only the more conserved $\mathrm{COOH}$-terminal part of the transposase protein were taken into account. These are a solitary transposase of IS1071 (Nakatsu et al., 1991) and a pair of closely related transposases of $\operatorname{Tn} 5041$ and $\operatorname{Tn} 4651$ (Fig. 3). Thus, sequence analysis of $\operatorname{Tn} 5041$ and $\operatorname{Tn} 4651$ transposases puts them on the fringe of the Tn 3 family. Yet, Tn5041 and $\operatorname{Tn} 4651$ are genuine $\operatorname{Tn} 3$ family transposons. Their transposases contain most of the invariant amino acid residues found in other transposases of the $\operatorname{Tn} 3$ family including a triad of acidic residues, D-D-E, which are candidates for catalytic residues (Yurieva \& Nikiforov, 1996).

Tn5041 encodes a protein showing homology to sitespecific recombinases of the integrase family

Typically, transposons of the $\operatorname{Tn} 3$ family encode enzymes of the resolvase family which are used for resolution of cointegrates formed during transposition. The exceptions include IS1071 which lacks resolvase (Nakatsu et al., 1991) and Tn4430 and Tn5401, both 


\section{Domain 1}

OrfI $\operatorname{Tn} 5041$

Cre P1

XerD E.Coli

XerC E.Coli

Int integron

TnpA Tn554

TnpI Tn 4430
* ${ }^{\star}$

TLL. IA. IARIRVKD

TGL.V....G.T.SD

AGL. L....G.DIKH

TGM. I. . GLQ. RVKD

.GL. IG.VLS. RLED

TGV.I. . ALSIK.ND
Domain 2

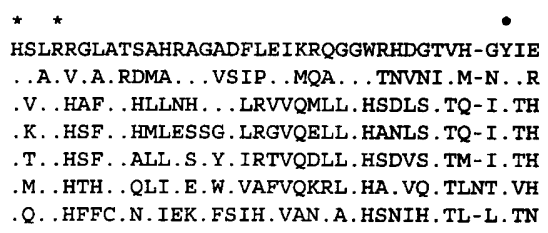

* *

. A.V.A. RDMA . . VSIP . MQA . . TNVNI . M-N . . R

V. . HAF . HLLNH . . LRVVQMLL . HSDLS . TQ - I . TH

M. . HTH . QLI . E.W. VAFVQKRL. HA . VQ . TLNT . VH

Q. . HFFC.N. IEK.FSIH. VAN. A. HSNIH. TL-L. TN
Fig. 4. Integrase-like domains (Argos et al., 1986; Abremski \& Hoess, 1992) of a putative resolvase of Tn5041 encoded by orfl. Orfl is aligned with its nearest neighbours from the integrase family in the order of closest similarity over the sequences shown. Dots represent bases identical with those in the upper sequence. Dashes represent bases absent in other sequences. Invariant amino acid residues which are believed to be involved in catalysis are marked by asterisks. Accession nos: Cre P1, X03453; XerD E. coli, M54884; XerC E. coli, P22885; Int of integrons, J02967; TnpA Tn554, X03216; Tnpl Tn4430, X07651. from Bacillus thuringiensis, which use integrase-like proteins as resolvases (Mahillon \& Lereclus, 1988; Baum, 1994, 1995). Database search revealed no Tn5041 genes encoding resolvase/invertase family proteins but detected that orfl, one of the two divergent ORFs located at the left arm of $\mathrm{Tn} 5041$, encoded a protein showing homology to phage $\mathrm{P} 1 \mathrm{Cre}$ and E. coli XerD proteins. These proteins are well known representatives of a large family of integrases involved in various sitespecific recombination processes (Nash, 1996). Although the members of the integrase family exhibit a large diversity in their sequences, they share four invariant amino acid residues, the RHRY tetrad, in two characteristic regions, named domain 1 and domain 2 (Argos et al., 1986; Abremski \& Hoess, 1992). The tetrad is believed to be involved in catalysis (Chen et al., 1992). The predicted Orfl protein of Tn5041 shows 28-34\% similarity to its nearest neighbours (including phage, chromosomal, integron and transposon integrases) in the two conserved domains (Fig. 4); similarity to more distant members of the family is about $20 \%$. Tn5041 OrfI contains all of the RHRY tetrad residues in the proper positions (Fig. 4). On this basis we suggest that orfl encodes a functional protein involved in recombination, most probably in the resolution of cointegrates formed during transposition of Tn5041. Identification of an integrase-like OrfI protein encoded by Tn5041 suggests that integrase-like resolvases are not unique to transposons of $B$. thuringiensis. Direct comparison of resolution systems of $\operatorname{Tn} 5041$ and its relative, $\operatorname{Tn} 4651$, is not possible since Tn4651 resolution genes mapped by Tsuda et al. (1989) are not yet sequenced. Our Southern hybridization experiments revealed no homology of Tn5041 orfl or divergently transcribed orfQ of unknown function with a toluene degradative plasmid $\mathrm{pWWO}$ which contains Tn4651 (data not shown). This demonstrates that the resolution systems of $\operatorname{Tn} 5041$ and Tn4651 are not as closely related as their IRs and transposases.

The sites of action of site-specific recombinases are often located upstream of their genes and comprise a functional core composed of a segment, called the overlap region, flanked by inverted repeats. For different members of the integrase family, the overlap region is
6-8 bp long while the repeats are $10-12$ bp long. The invertases recognize the inverted half-sites and cleave and exchange DNA strands via the transient formation of a covalent linkage of the conserved $T y r$ residue with the 3 ' ends flanking the overlap region (for review see $\mathrm{Nash}, 1996)$. Inspection of the sequence upstream of orfI revealed a 34 bp non-perfect palindromic sequence as a candidate functional core of the $\operatorname{Tn} 5041$ resolution site (Fig. 1). This putative site has a striking similarity to the E. coli chromosomal dif site. This suggests that the OrfImediated strand cleavage/exchange occur $3^{\prime}$ to the ATAA dyad portions (shared with dif and boxed in Fig. 1) separated by 6 bp central region. It should be noted that dif is operated by two proteins, XerD and XerC, showing $37 \%$ overall sequence identity (Blakely et al., 1993), but no such closely related partner of Orfl is encoded by Tn5041. Besides the functional core, the recombination locus may include extra binding sites for the recombinase and/or binding sites for accessory proteins. This is believed to provide additional asymmetry to recombinational loci to ensure directionality of the recombination process (Sherratt et al., 1995). For example, the Tn5401 locus involved in cointegrate resolution contains two extra binding sites for a transposon-encoded integrase-like TnpI protein. These extra sites are represented by direct repeats of single copies of the half-sites of the functional core (Baum, 1995). No extra core half-site copies or obvious binding sites for accessory proteins such as those found in ColE1 cer (Stirling et al., 1988) were found around the putative resolution site of $\operatorname{Tn} 5041$. Further characterization of the putative resolution locus of $\operatorname{Tn} 5041$ requires a biochemical approach.

\section{Tn5041 contains a functional mer operon showing $70 \%$ sequence similarity to the mer operons of Tn21 and Tn501}

The central part of Tn5041 is occupied by a wellrecognized mer operon (Fig. 1) showing $70 \%$ similarity to mer operons of classical mercury resistance transposons $\operatorname{Tn} 21$ and $\operatorname{Tn} 501$. The mer operon of $\operatorname{Tn} 5041$ is preceded by a 24 bp element showing $75 \%$ sequence similarity to the outermost part of IRs typical for Tn21like transposons. As in Tn21-like transposons, the 


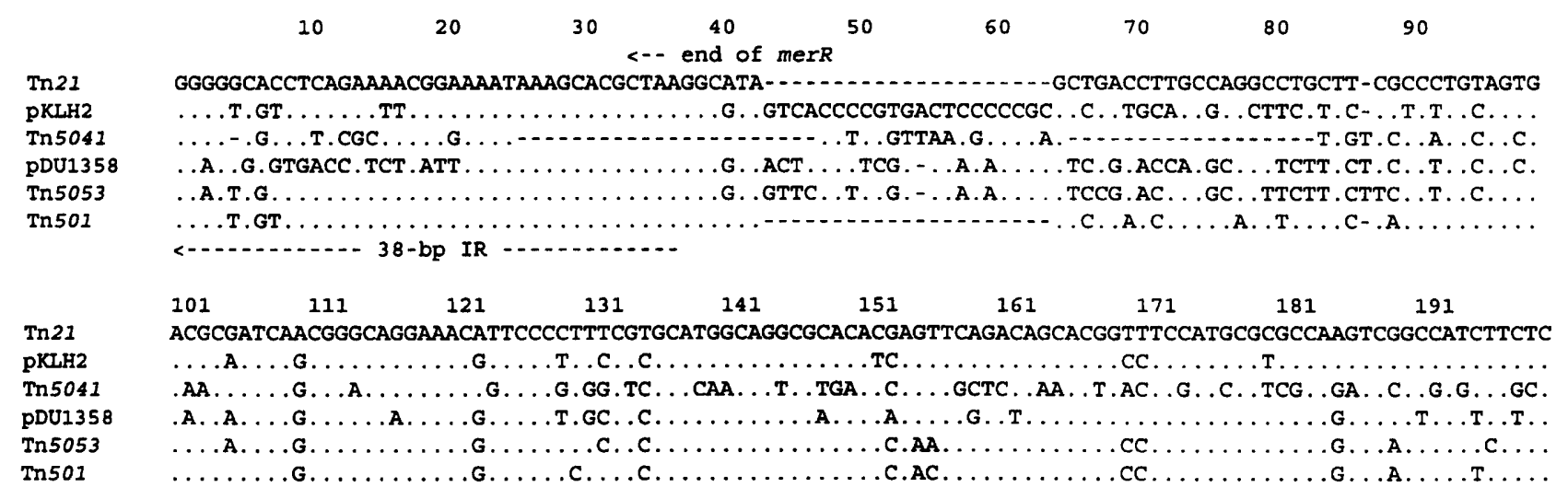

Fig. 5. Sequence alignment of the beginning of the mer operon of Tn5041 with the mer operons from various Gramnegative bacteria. The inverted repeats (IRs) are underlined. Note that the IRs of Tn501 and Tn5053 shown are located within the corresponding transposons (Grinsted \& Brown, 1984; Kholodii et al., 1993). The stop codon position and direction of translation of merR gene of Tn21 is shown by arrow. Dots represent bases identical with those in the upper sequence. Dashes represent bases absent in other sequences. Accession nos: Tn21, J01730; pKLH2, L04303; pDU1358, M24940; Tn5053, L40585; Tn501, X03406.

truncated IR is fused to a regulatory gene merR (Fig. 5). The $m e r R$ gene is followed by the structural genes merT, $P$ and $C$ which control transport of mercury ions and merA which encodes mercury reductase. Then follows an ORF, orf Y. In this position, some mer operons contain a merB gene which encodes organomercurial lyase that confers resistance to organomercurials (Misra, 1992). However orf $Y$ shows no homology to known merB (Reniero et al., 1995) or any other genes. Moreover, our experiments have demonstrated that the mer operon of Tn5041 does not confer organomercurial resistance (for details see Methods). Thus the function of orfY remains obscure. This is then followed by merD (which is thought to be involved in the fine regulation of mer operons) and two ORFs, urf-1 and urf-2, of unknown function. The latter contains a large deletion compared with $\operatorname{Tn} 501$.

\section{Tn5041 contains a $4 \mathrm{~kb}$ region with relics of mobile elements and shortened genes}

The $4 \mathrm{~kb}$ region between orfQ and the mer operon of Tn5041 contains traces of multiple rearrangements resulting in formation of apparently non functional genes and mobile elements. One such element $(\kappa \gamma$ in Fig. 1 ) is bound by $38 \mathrm{bp}$ non-perfect IRs which neatly fall into the family of IRs of the Tn 3 family (Fig. 2b). We noticed that IRs of $\kappa \gamma$ are closely related to the $38 \mathrm{bp}$ sequence (res501 in Fig. 2b) which is located between the end of the resIII site and the start codon of $\operatorname{tn} p R$ in $\operatorname{Tn} 501$ and $\operatorname{Tn} 1721$ but is absent in Tn21 and Tn3926. By searching nucleotide sequence databases we have identified previously unnoticed solitary $38 \mathrm{bp}$ elements closely related to IRs of $\kappa \gamma$ in the vicinity of the $a v r B$ gene of Pseudomonas syringae (Tamaki et al., 1988) and $m k a D$ ( $m k f A$ ) gene found in virulence plasmids of numerous Salmonella strains (Taira \& Rhen, 1990; Matsui et al., 1990). Another defective element ( $\sigma \lambda$ in Fig. 1) is a truncated copy of an IS element showing $60 \cdot 6 \%$ nucleotide sequence similarity to IS2 and $59 \cdot 4 \%$ similarity to ISRm1 (Watson \& Wheatcroft, 1991). A truncated copy of mer $R\left(R^{\prime}\right.$ in Fig. 1) showing $94.3 \%$ nucleotide sequence similarity to the functional copy $m e r R$ of $\operatorname{Tn} 5041$ is located between $\sigma \lambda$ and $\kappa \gamma$ (Fig. 1). Traces of two membrane protein genes can be pinpointed in the $4 \mathrm{~kb}$ region. One of these is represented by an ORF, orfP, with a reasonable Shine-Dalgarno sequence (Fig. 1). The predicted translation product shows about $30 \%$ sequence similarity to a central segment of $P$. aeruginosa porins D2 and E1. No specific functions have been ascribed to this segment in the porin molecule (Yamano et al., 1993). Relics of another putative membrane protein gene are represented by four short reading frames. Segments of proteins translated from these frames show similarity to different segments of a rat integral membrane protein described by Hallberg et al. (1993) (Fig. 1). These speculations can be confirmed only by finding more closely related functional bacterial porins.

\section{Tn5041 is a chimera composed of several modules that have different origins}

In conclusion, our sequence analysis demonstrates that both the mer operon module and the transposition module of Tn 5041 show relationships to known mobile elements. The mer operon module of Tn5041 displays $70 \%$ nucleotide sequence similarity to the mer operons of the well-known Tn21-like transposons and carries 3' to the stop codon of its merR a truncated copy of IR typical of these transposons. The transposase gene and IRs of Tn5041 are very similar to those of a toluene degradative transposon, Tn4651, but are very distantly related to those of Tn21-like transposons. Accordingly, we consider Tn5041 as a chimera which obtained its mer operon as a result of insertion of a transposon belonging to Tn21 subgroup into a transposon related to Tn4651 followed by deletion of primary (Tn21-type) trans- 
position genes. Similar insertion-deletion events occurred during the genesis of quite different mercury resistance transposons, Tn5053 (Kholodii et al., 1993, 1995 ) and Tn501 (Grinsted \& Brown, 1984). It seems that relays of transposition modules from the primary Tn21-like transposons to various other types is a common feature of the lifestyle of mer operons. Besides the mer operon and putative transposition genes, Tn5041 contains a $4 \mathrm{~kb}$ region of unknown origin and significance which accommodates a number of apparently defective mobile elements. This suggests that Tn5041-like transposition modules were used as vehicles by numerous passenger genes other than mercury resistance or toluene degradative operons.

\section{ACKNOWLEDGEMENTS}

This work was supported in part by the Russian State Program Frontiers in Genetics, and National Institutes of Health FIRCA Grant TW00396-02. We thank Dr R. Novick for support, $\operatorname{Dr} \mathrm{N}$. Brown and two anonymous referees for comments and helpful suggestions, and Drs K. N. Timmis and J. Grinsted for gifts of plasmids.

\section{REFERENCES}

Abremski, K. E. \& Hoess, R. H. (1992). Evidence for a second conserved arginine residue in the integrase family of recombination proteins. Protein Eng 5, 87-91.

Altschul, S. F., Gish, W., Miller, W., Myers E. W. \& Lipman, D. J. (1990). Basic local alignment search tool. J Mol Biol 215, 403-410.

Amuthan, G. \& Mahadevan, A. (1994). Replicon typing of plasmids of phytopathogenic xanthomonads. Plasmid 32, 328-332.

An, F. Y. \& Clewell, D. B. (1991). Tn917 transposase: sequence correction reveals a single open reading frame corresponding to the $\operatorname{tnp} A$ determinant of Tn3-family elements. Plasmid 25, 121-124.

Argos, P., Landy, P., Abremski, K., Egan, J. B., HaggardLjungquist, E., Hoess, R. H., Kahn, M. L., Kalionis, B., Narayana, S. V. L., Pierson, L. S., III, Sternberg, N. \& Leong, J. M. (1986). The integrase family of site-specific recombinases: regional similarities and global diversity. $E M B O J \mathbf{5}, 433-440$.

Arthur, M., Molinas, C., Depardieu, F. \& Courvalin, P. (1993). Characterization of $\operatorname{Tn} 1546$, a $\operatorname{Tn} 3$-related transposon conferring glycopeptide resistance by synthesis of depsipeptide peptidoglycan precursors in Enterococcus faecium BM4147. J Bacteriol 175, 117-127.

Barton, B. M., Hardling, G. P. \& Zuccarelli, A. J. (1995). A general method for detecting and sizing large plasmids. Anal Biochem 226, 235-240.

Baum, J. A. (1994). Tn5401, a new class II transposable element from Bacillus thuringiensis. J Bacteriol 176, 2835-2845.

Baum, J. A. (1995). TnpI recombinase: identification of sites within Tn5401 required for TnpI binding and site-specific recombination. J Bacteriol 177, 4036-4042.

Birnboim, H. \& Doly, J. (1979). A rapid alkaline extraction procedure for screening recombinant plasmid DNA. Nucleic Acids Res 7, 1513-1523.

Blakely, G., May, G., McCulloch, R., Arciszewska, L. K., Burke, M., Lovett, S. T. \& Sherratt, D. J. (1993). Two related recombinases are required for site-specific recombination at dif and cer in E. coli K12. Cell 75, 351-361.
Bogdanova, E. S., Mindlin, S. Z., Kalyaeva, E. S. \& Nikiforov, V. G. (1988). The diversity of mercury reductases among mercuryresistant bacteria. FEBS Lett 234, 280-282.

Brown, H. J., Stokes, H. W. \& Hall, R. M. (1996). The integrons In0, In2, and In 5 are defective transposon derivatives. J Bacteriol 178 , 4429-4437.

Chen, J.-W., Lee, J. \& Jayaram, M. (1992). DNA cleavage in trans by the active site tyrosine during Flp recombination: switching protein partners before exchanging strands. Cell 69, 647-658.

Chiou, C.-S. \& Jones, A. L. (1993). Nucleotide sequence analysis of a transposon (Tn5393) carrying streptomycin resistance genes in Erwinia amylovora and other gram-negative bacteria. $J$ Bacteriol 175, 732-740.

Eckhardt, T. (1978). A rapid method for identification of plasmid desoxyribonucleic acid in bacteria. Plasmid 1, 584-588.

Elhai, J., Cai, Y. \& Wolk, P. C. (1994). Conduction of pEC22, a plasmid coding for MR.EcoT22I, mediated by a resident Tn3like transposon, Tn5396. J Bacteriol 176, 5059-5067.

Friello, D. A. \& Chakrabarty, A. M. (1980). Transposable mercury resistance in Pseudomonas putida. In Plasmids and Transposons: Environmental Effects and Maintenance Mechanisms, pp. 249-259. Edited by C. Stuard \& K. R. Rozee. New York: Academic Press.

Grinsted, J. \& Brown, N. L. (1984). A Tn21 terminal sequence within $\operatorname{Tn} 501$ : complementation of $\operatorname{tnp} A$ gene function and transposon evolution. Mol Gen Genet 197, 497-502.

Grinsted, J., de la Cruz, F., Altenbuchner, J. \& Schmitt, R. (1982). Complementation of transposition of $\operatorname{tnp} A$ mutants of $\operatorname{Tn} 3$, Tn21, Tn501, and Tn1721. Plasmid 8, 276-286.

Grinsted, J., de la Cruz, F. \& Schmitt, R. (1990). The Tn21 subgroup of bacterial transposable elements. Plasmid 24, 163-189.

Hallberg, E., Wozniak, R. W. \& Blobel, G. (1993). An integral membrane protein of the pore membrane domain of the nuclear envelope contains a nucleoporin-like region. J Cell Biol 122, 513-521.

Ivey, D. M., Guffanti, A. A, Shen, Z., Kudyan, N. \& Krulwich, T. A. (1992). The cadC gene product of alkaliphilic Bacillus firmus OF4 partially restores $\mathrm{Na}^{+}$resistance to an Escherichia coli strain lacking an $\mathrm{Na}^{+} / \mathrm{H}^{+}$antiporter (NhaA). J Bacteriol 174, $4878-4884$.

Kelly, W. J. \& Reanney, D. C. (1984). Mercury resistance among soil bacteria: ecology and transferability of genes encoding resistance. Soil Biol Biochem 16, 1-8.

Khesin, R. B. \& Karasyova, E. V. (1984). Mercury-resistant plasmids in bacteria from a mercury and antimony deposit area. Mol Gen Genet 197, 280-285.

Kholodii, G., Yurieva, O., Lomovskaya, O., Gorlenko, Zh., Mindlin, S. \& Nikiforov, V. (1993). Tn5053, a mercury resistance transposon with integron's ends. $J \mathrm{Mol}$ Biol 230, 1103-1107.

Kholodii, G. Ya., Mindlin, S. Z., Bass, I. A., Yurieva, O. V., Minakhina, S. V. \& Nikiforov, V. G. (1995). Four genes, two ends, and a res region are involved in transposition of Tn5053: a paradigm for a novel family of transposons carrying either a mer operon or an integron. Mol Microbiol 17, 1189-1200.

Lebrun, M., Audurier, A. \& Cossart, P. (1994). Plasmid-borne cadmium resistance genes in Listeria monocytogenes are present on $\operatorname{Tn} 5422$, a novel transposon closely related to $\operatorname{Tn} 917$. $J$ Bacteriol 176, 3049-3061.

Lett, M.-C., Bennett, P. M. \& Vidon, D. J.-M. (1985). Characterization of Tn3926, a new mercury-resistance transposon from Yersinia enterocolitica. Gene 40, 79-91. 
Mahillon, J. \& Lereclus, D. (1988). Structural and functional analysis of $\operatorname{Tn} 4430$ : identification of an integrase-like protein involved in the cointegrate-resolution process. EMBO $J$, 1515-1526.

Mahler, I., Levinson, H. S., Wang, Y. \& Halvorson, H. O. (1986). Cadmium- and mercury-resistant Bacillus strains from a salt marsh and from Boston Harbor. Appl Environ Microbiol 52, 1293-1298.

Matsui, H., Kawahara, K., Terakado, N. \& Danbara, H. (1990). Nucleotide sequence of a gene encoding a $29 \mathrm{kDa}$ polypeptide in mba region of the virulence plasmid, pKDSC50, of Salmonella choleraesuis. Nucleic Acids Res 18, 1055.

Misra, T. K. (1992). Bacterial resistances to inorganic mercury salts and organomercurials. Plasmid 27, 4-16.

Nakatsu, C., Ng, J., Singh, R., Straus, N. \& Wyndham, C. (1991). Chlorobenzoate catabolic transposon $\operatorname{Tn} 5271$ is a composite class I element with flanking class II insertion sequences. Proc Natl Acad Sci USA 88, 8312-8316.

Nash, H. A. (1996). Site-specific recombination: integration, excision, resolution, and inversion of defined DNA segments. In Escherichia coli and Salmonella typhimurium: Cellular and Molecular Biology, 2nd edn, vol. 2, pp. 2363-2376. Edited by F. C. Neidhardt and others. Washington, DC: American Society for Microbiology.

Osbourn, S. E. V., Turner, A. K. \& Grinsted, J. (1995). Nucleotide sequence within Tn3926 confirms this as Tn21-like transposable element and provides evidence for the origin of the mer operon carried by plasmid pKLH2. Plasmid 33, 65-69.

Pansegrau, W., Lanka, E., Barth, P. T., Figurski, D. H., Guiney, D. G., Haas, D., Helinski, D. R., Schwab, H., Stanisich, V. A. \& Thomas, C. M. (1994). Complete nucleotide sequence of Birmingham IncP plasmids. Compilation and comparative analysis. J Mol Biol 239, 623-663.

Radford, A. J., Oliver, J., Kelly, W. J. \& Reanney, D. C. (1981). Translocatable resistance to mercuric and phenylmercuric ions in soil bacteria. J Bacteriol 147, 1110-1112.

Reniero, D., Galli, E. \& Barbieri, P. (1995). Cloning and comparison of mercury-and organomercurial resistance determinants from a Pseudomonas stutzeri plasmid. Gene 166, 77-82.

Sambrook, J., Fritsch, E. F. \& Maniatis, T. (1989). Molecular Cloning: a Laboratory Manual, 2nd edn. Cold Spring Harbor, NY: Cold Spring Harbor Laboratory.

Schottel, J., Mandal, A., Clark, D., Silver, S. \& Hedges, R. W. (1974). Volatilization of mercury and organomercurials determined by inducible R-factor systems in enteric bacteria. Nature 251, 335-337.

Sherratt, D. J., Arciszewska, L. K., Blakely, G., Colloms, S., Grant, K., Leslie, N. \& McCulloch, R. (1995). Site-specific recombination and circular chromosome segregation. Phil Trans R Soc Lond B 347, 37-42.

Shiratori, T., Inoue, C., Sugawara, K., Kusano, T. \& Kitagawa, Y. (1989). Cloning and expression of Thiobacillus ferrooxidans mercury ion resistance genes in Escherichia coli. J Bacteriol 171, 3458-3464.

Siemieniak, D. R., Slightom, J. L. \& Chung, S.-T. (1990). Nucleotide sequence of Streptomyces fradiae transposable element Tn4556: a class-II transposon related to Tn3. Gene 86, 1-9.

Silver, S. \& Walderhaug, M. (1992). Gene regulation of plasmidand chromosome-determined inorganic ion transport in bacteria. Microbiol Rev 56, 195-228.

Smith, C. A. \& Thomas, C. M. (1987). Comparison of the organization of the genomes of phenotypically diverse plasmids of incompatibility group $\mathrm{P}$ : members of the $\operatorname{IncP} \beta$ subgroup are closely related. Mol Gen Genet 206, 419-427.

Stanisich, V. A., Bennett, P. M. \& Richmond, M. H. (1977). Characterization of a translocation unit encoding resistance to mercuric ions that occurs on a nonconjugative plasmid in Pseudomonas aeruginosa. J Bacteriol 129, 1227-1233.

Stanisich, V. A., Arwas, R., Bennett, P. M. \& de la Cruz, F. (1989). Characterization of Pseudomonas mercury-resistance transposon Tn502, which has a preferred insertion site in RP1. J Gen Microbiol 135, 2909-2915.

Stirling, C. J., Sztmari, G., Stewart, G., Smith, M. C. M. \& Sherratt, D. J. (1988). The arginine repressor is essential for plasmidstabilizing site-specific recombination at the ColE1 cer locus. EMBO J 7, 4389-4395.

Taira, S. \& Rhen, M. (1990). Nucleotide sequence of $m k a D$, a virulence-associated gene of Salmonella typhimurium containing variable and constant regions. Gene 93, 147-150.

Tamaki, S., Dahlbeck, D., Staskawicz, B. \& Keen, N. T. (1988). Characterization and expression of two avirulence genes cloned from Pseudomonas syringae pv. glycinea. I Bacteriol 170, 4846-4854.

Tsuda, M., Minegishi, K.-I. \& lino, T. (1989). Toluene transposons Tn4651 and Tn4653 are class II transposons. J Bacteriol 171, 1386-1393.

Turner, A. K. \& Grinsted, J. (1987). DNA sequence of the transposase gene of the new category of class II transposon, Tn2501. Nucleic Acids Res 15, 10049.

Ulrich, A. \& Puehler, A. (1994). The new class II transposon Tn163 is plasmid-borne in two unrelated Rhizobium leguminosarum biovar viciae strains. Mol Gen Genet 242, 505-516.

Wang, Y., Mahler, I., Levinson, H. S. \& Halvorson, H. O. (1987). Cloning and expression in Escherichia coli of chromosomal mercury resistance genes from a Bacillus sp. J Bacteriol 169, 4848-4851.

Watson, R. \& Wheatcroft, R. (1991). Nucleotide sequence of Rhizobium meliloti insertion sequence ISRm1: homology to IS2 from Escherichia coli and IS426 from Agrobacterium tumefaciens. DNA Seq 2, 163-172.

Witte, W., Green, L., Misra, T. K. \& Silver, S. (1986). Resistance to mercury and to cadmium in chomosomally resistant Staphylococcus aureus. Antimicrob Agents Chemother 29, 663-669.

Womble, D. D. \& Rownd, R. H. (1988). Genetic and physical map of plasmid NR1: comparison with other IncFII antibiotic resistance plasmids. Microbiol Rev 52, 433-451.

Yamano, Y., Nishikawa, T. \& Komatsu, Y. (1993). Cloning and nucleotide sequence of anaerobically induced porin protein E1 (OprE) of Pseudomonas aeruginosa PAO1. Mol Microbiol 8, 993-1004.

Yurieva, O. \& Nikiforov, V. (1996). Catalytic center quest: comparison of transposases belonging to the $\operatorname{Tn} 3$ family reveals an invariant triad of acidic amino acid residues. Biochem $\mathrm{Mol}$ Biol Int 38, 15-20.

Zharkikh, A. A., Rzhetsky, A. Yu., Morosov, P. S., Sitnikova, T. L. \& Krushkal, J. S. (1991). vosTORG: a package of microcomputer programs for sequence analysis and construction of phylogenetic trees. Gene 101, 251-254.

Received 20 November 1996; revised 10 March 1997; accepted 15 April 1997. 